\title{
Financial liberalization and structural change: the Brazilian case in the 2000 s *
}

\author{
Carmem Feijo ${ }^{* *, * * *}$ \\ Marcos Tostes Lamônica * \\ Serigiano Silva Lima ${ }^{* * * * *}$
}

\begin{abstract}
This paper discusses the relationship between financial integration and structural change based on a MinskyKregel approach. The motivation for this investigation derives from the fact that the opening of the Brazilian economy in the 1990s did not generate a structural change capable of increasing the weight of highertechnological sectors in the manufacturing industry. In theoretical terms we assume that financial liberalization in developing countries induces the loss in importance of the industrial sector in the productive structure, leading to an early deindustrialization process. In addition, it increases the external fragility and reduces the scope for developing countries to implement long-term economic policies to increase their potential output. In our econometric exercise applied to the Brazilian economy in the 2000s it was observed that financial integration and dependence on foreign savings, captured by an international liquidity proxy and dummy variables to incorporate the external financial instability in the period studied, reduced the share of Brazilian industry in GDP.
\end{abstract}

Key words: Financial liberalization, Policy space, Brazilian economy.

\section{Resumo}

\section{Liberalização financeira e mudança estrutural: o caso brasileiro nos anos 2000}

A partir de uma abordagem Minsky-Kregel, este paper discute a relação entre integração financeira e mudança estrutural. Ou seja, a abertura da economia brasileira nos anos 1990 não gerou a mudança estrutural capaz de elevar o peso dos setores de maior conteúdo tecnológico na indústria de transformação. Assume-se que a liberalização financeira nos países em desenvolvimento induz a perda de importância do setor industrial na estrutura produtiva, levando a economia a um processo precoce de desindustrialização, como ocorreu no Brasil. Além disso, aumenta a fragilidade externa e reduz o espaço de manobra para os países em desenvolvimento implementarem políticas de longo prazo que aumentem seu produto potencial. Em nosso exercício econométrico aplicado à economia brasileira nos anos 2000, foi observado que a integração financeira e a dependência da poupança externa, capturados por um índice de liquidez internacional e variáveis dummy para incorporar a instabilidade financeira externa no período analisado, reduziu a participação da indústria brasileira no PIB.

Palavras-chave: Liberalização financeira; Espaço de política; Economia brasileira. JEL O11, O14.

* Article received on June 22, 2016 and approved on October 29, 2017. The authors wish to thank an anonymous reviewer for helpful comments. All remaining errors are the authors' responsibility.

${ }^{* *}$ Professor at the Federal Fluminense University (UFF), Niteroi, RJ, Brazil. E-mail: cbfeijo@ gmail.com.

${ }^{* * *}$ Researcher at National Council for Scientific and Technological Development (CNPq), Brasília, DF, Brazil.

${ }^{* * * *}$ Professor at the Federal Fluminense University (UFF), Niteroi, RJ, Brasil. E-mail: marcoslamonica@id.uff.br.

****** Professor of Economics at the Academic Unit of Serra Talhada (UAST) of Rural Federal University of Pernambuco (UFPe), Serra Talhada, PE, Brazil. E-mail: segiany@yahoo.com.br. 


\section{Introduction}

The opening of emerging economies, one of the main pillars of the neoliberal agenda, assumes that economic liberalization, including financial markets, would have a positive impact on growth as it would allow the absorption of foreign savings, on one hand, and the increase of competition with foreign competitors, on the other. Moreover, according to the neoliberal agenda, capital opening should allow developing countries to accumulate technological capabilities and reduce their dependence on the growth of foreign currency. In our view, the catching up process that would enhance the growth potential of developing economies actually requires a different economic policy agenda to the one proposed by the neoliberal agenda. The main reason is because policy space is greatly reduced in economies that are dependent on foreign savings and are financially integrated, and so economic opening might impair the catching up process and induce developing economies to become specialized in low income elasticity goods and so condemned to low long-term growth rates. Regarding the Brazilian economy, the benefits in terms of increased growth have not been observed since the 1990s, since Brazil joined the Brady Plan to solve its external debt problem and embraced most of the Washington Consensus recommendations ${ }^{1}$.

Indeed, after two and a half decades of economic opening, the Brazilian economy has not yet recovered its previous levels of growth, and a structural change is taking place leading to an accelerated loss of weight of the manufacturing sector. From 1996 to 2016, GDP growth rate was 2.4 per cent a year, and the industrial sector expanded 1.3 per cent on average in the same period. The manufacturing industry, the most dynamic sector, stagnated, expanding only 0.6 per cent on average. In terms of the composition of aggregate output, the share of the industrial sector has been falling in total value added since 1996, at which time it contributed with 25.5 per cent, reaching 21.2 per cent in 2016. The share of the manufacturing sector, in turn, decreased from 14.9 per cent in 1996 to 12.5 per cent in $2016^{2}$. It should be noted that the de-industrialisation process has been in motion since economic opening, in spite of the launch of policy incentives to stimulate the sector, which include: the Sustaining Plan of Investment (PSI- Plano de Sustentação do Investimento) that aimed to increase the disbursement of the Brazilian Development Bank (BNDES) to encourage productive investment; the Plano Brasil Maior (Greater Brazil Plan) launched in April 2013 based on several strategic actions (largely tax exemptions or reductions and innovation incentives) in different sectors, such as capital goods, automobiles, information technology and communication, oil and gas, chemical and others, as well as incentives to invest in

(1) For developing countries, the deepening of the financialization process is closely linked to the capital account liberalization that was part of the neoliberal structural reforms that took place from the end of the 1980s. According to Painceira (2009) the Brady Plan, in the early 1990s, can be considered the beginning of the financial liberalization process in Latin American economies, and of the Brazilian economy in particular. Sicsú (2006) gives a description of the changes to the rules of the domestic exchange market in Brazil in the 2000s in order to advance the financial integration of the country. See also Biancarelli (2010) and Carneiro (1999), among others.

(2) For a recent discussion on the effects of globalization on de-industrialization considering a large sample of emerging countries, see Rodrik (2016). 
infrastructure ${ }^{3}$. The slow response of the industrial sector to the economic policy stimuli brought almost full consensus in academia that the de-industrialization process might have gone too far ${ }^{4}$.

The aim of this paper is to discuss how financial liberalization is contributing to the fall in importance of the industrial sector in total output. Our assumption is that financial integration of the Brazilian economy has narrowed its policy space and increased its external financial fragility. In such a macroeconomic context, structural change moved towards specialization of the industrial sector in natural resources production, leading to an early deindustrialization process.

The paper is divided into six sections, in addition to this brief introduction. In section two we discuss how developing economies engage in a Ponzi scheme when opening their economies and jeopardize their opportunity to promote structural change to increase longterm growth rates. In section three we present microeconomic arguments to explain how the narrowing of policy space due to financial integration impairs potential output growth. Section four presents the evolution of the Brazilian economy in the 2000s showing how external financial deepening is making the economy more susceptible to external shocks, i.e., the economy is moving towards a Ponzi financial scheme. Section five presents a simple econometric model to illustrate the relation between structural change and financial integration. The final section presents our conclusions.

\section{Why should developing economies not open their financial account?}

The core proposition of financial liberalization advocates freeing financial markets of any intervention. If developing economies follow this basic proposition, the excess capital in the financial markets of developed countries would be aimed at developing countries that offer higher rates of return. A clear assumption is that capital movement would behave in a countercyclical way. Therefore, developing countries should benefit from an increased supply of credit to boost investment and thereby accelerate economic growth.

In the early 1970s, McKinnon (1973) and Shaw (1973) were the main authors to provide a theoretical background to capital liberalization. They gave that the poor performance of investment and growth in developing countries was due to the extensive use of interest rate controls and other instruments aimed at directing private credit to selected sectors. These restrictions would be responsible for imposing 'financial repression', which would be associated to inefficiency in the intermediation of resources by the financial system. Hence, the 'financial repression' would explain a low rate of savings, credit rationing and low investment, leading to low growth and eventually to economic stagnation. Capital account liberalization and liberal reforms of the financial system would, therefore, provide an

(3) For a summary of the main policy measures to incentivize the industrial sector, see Nassif and Feijo (2013, Table 3).

(4) See Bacha and de Bolle (2013) and Azevedo et al. (2013), among others, regarding the recent debate on deindustrialization in Brazil. 
alternative to increase domestic saving and investment, allowing greater capital flow through loans to domestic banks, foreign direct investment and portfolio. In more general terms, financial liberalization would enable the global allocation of savings and help channel resources to the productive sector, increasing the economic long-term growth of developing countries.

However, after over three decades of capital account liberalization in most economies, the results of financial liberalization are not reassuring for either developed nor developing economies. As pointed out by Arestis (2006), for both economies, the advances in the liberalization reforms in the early 1980 s on the financial system have increased the frequency and severity of banking crises, with impacts on the real economy, since they imply a downturn in economic activity for the local economies involved. On the other hand, as pointed out by Ocampo and Stiglitz (2008), for developing economies, the pro-cyclical nature of short-term capital flows has chracterised the main pattern of capital movement, increasing the macroeconomic volatility of their economies, and undermining their growth prospects.

The pro-cyclical nature of capital movement is observed either when foreign lenders sharply cut new lending and refuse to roll over old loans when they are needed (when lenders' expectation become risk avert), or when domestic investors, anticipating a devaluation in their currencies, precipitate a capital flight. These patterns were largely registered in the balance of payments crisis in the 1990s in Asia and Latin America. Moreover, according to Ocampo and Stiglitz (op. cit), the instability in capital flows is not only observed in short-term speculative flows, but also in longer term portfolio investments, including foreign investment. Although volatility in this latter case is much less accentuated, nowadays foreign investment is mostly in bond issues and bond financing which are strongly pro-cyclical.

It is in this sense that financially integrated developing economies are prone to augmented financial fragility. According to Kregel (1999), Minsky's definition of financial fragility can be understood as the result of changes in the liquidity preferences of bankers and businessmen as represented by changes in the margins of safety required on liquidity creation produced by maturity transformation. Applying this definition to developing economies that supplement their domestic savings with foreign savings, in other words, with positive net international lending, Kregel (2004, p. 580) concludes that "by definition and by design, [developing economies will be] operating a "Ponzi" financial profile since the interest and amortization on the borrowing can only be met by additional foreign capital inflows". This implies that for a country to be successful in engaging in foreign indebtedness to finance its growth in a financially integrated world means that "its success depends on the willingness of foreign lenders to continue to lend".

Kregel (2004, p. 580) presents two strategies to be followed by the country:

[...] to ensure continued lending - by building "real" capital or by building "financial" capital. Building "real" capital means using the foreign lending to invest in projects that 
ensure that the share of net exports in gross domestic product (GDP) rises so that foreign exchange earnings eventually rise to the point at which they cover financing commitments created by the borrowing. [...] On the other hand, building "financial" capital means increasing lenders' confidence in their decision to lend so they continue to increase lending in sufficient amounts to ensure that existing debt service commitments can be met. [...] this approach requires ensuring the lenders of these countries' continued ability to borrow in order to meet foreign currency commitments and the continued success of the Ponzi game.

Following Kregel's view, the building of 'real' capital would imply that the opening of the economy should allow domestic producers time to promote restructuring programs to improve productivity to face increased external competition. Only if the country is successful in promoting a structural change towards the production of more sophisticated goods and services, the condition to build 'financial' capital to meet the rising current account deficits would be accomplished. But if this is not the case, the country's only alternative is to influence its international risk premium (Kregel, 2004, p. 582). It is clear then that, in such a context, room for maneuver to conduct macroeconomic policy is narrowed to promote the much-needed structural change required to improve trade balance to fulfill debt commitments of the service balance .

Moreover, the macroeconomic context of developing economies is one of enhanced financial fragility given the pro-cyclical profile of international capital flows. In this overall context, according to Kregel (op. cit.), where economies must demonstrate a commitment to repay their debts by influencing the confidence of the lender, the only policy instrument under their control is public debt. Therefore, the fiscal policy is pro-cyclical, thus the fiscal space becomes narrower, given that the size of deficits and debts are seen by the market as a threat to a fiscal crisis. Therefore, if foreign markets perceive the threat of a fiscal crisis, Kregel (op.cit) concludes that they will not agree with continued borrowing.

Fiscal debt can be controlled by reducing the domestic interest rate. However, a financially integrated developing economy may not be able to do so because the interest rate differential is an important instrument to attract foreign capital. Also, if the economy is in the inflation target regime, the interest rate is the only instrument to control inflation. The interest rate differential, in turn, has a negative effect on the real exchange rate, that tends to be overvalued in the long-term. The maintenance of a high interest rate also deteriorates the

(5) For a discussion on the macroeconomics of developing economies, see Bresser-Pereira et al. (2015). According to the authors, open developing economies tend to exhibit a high real and nominal interest rate, a trend to overvaluation of the real exchange rate and for large countries endowed with cheap labour and abundant natural resources - the so-called Dutch disease. See also Ocampo (2013), where the author proposes a 'balance of payments dominance' view, to explain why macroeconomic volatility is increased in developing economies with open capital accounts. According to the author, this is so because in developing economies the capital account plays an important role in causing cyclical shocks, and therefore the financial cycles are stronger for those economies that are considered riskier by financial markets, because of their segmented integration into the global financial market. 
Carmem Feijo, Marcos Tostes Lamônica, Serigiano Silva Lima

public debt profile, condemning the economy to a low growth rate, as the fiscal space of the economy is constrained ${ }^{6}$.

In sum, the consequences of keeping real interest rate high, either to control inflation and/or to attract capital, a non-competitive real exchange rate and high fiscal surplus lead to low growth which makes the economy less attractive to foreign capital. As a result, the creation of 'financial' capital may be eroded.

Therefore, one conclusion that can be drawn from the strategy to use foreign savings (by accepting current account deficits) by financially integrated developing economies to boost growth, is that they will inevitably end up in a Ponzi scheme. Finally, it should be added that an attempt to accumulate reserves as an insurance to buy confidence, a strategy that was followed by most developing economies after the Asian crisis at the end of the 1990s, should consider their financial cost, that will be higher according to the level of the interest rate differential. If, as Carvalho (2009) argues, the strategy to accumulate reserves is advisable to 'buy time' in the case of a currency crisis, it is not a definite solution to the widening of policy space when developing economies open their economies.

\section{Why does potential output not increase with financial liberalization?}

We will now exploit microeconomic arguments to show why potential output and aggregate productivity do not increase with financial liberalization, as assumed by conventional literature. When capital account liberalization in developing economies is associated with a macroeconomic policy that preserves a relatively higher interest rate and an overvalued real exchange rate and pro-cyclical fiscal policy, there might not be a rise in the domestic investment rate resulting in lower potential output. This assumption derives from the negative correlation between the following variables: a) interest rate and the firm's cash flow; b) real exchange rate and the development of technological intensive productive sectors; c) real exchange rate and real wage rate that may increase labour unit cost above productivity, reducing the country's competitiveness and domestic savings.

In the first case, the interest rate will adversely affect investment in physical assets as much as the firm depends on debt to finance capital accumulation. In a scenario of increasing interest rates, the degree of the firm's indebtedness will rise, reducing the possibility to finance new investments. However, assuming, as in Kalecki, that firms rely mostly on retained profits to finance capital accumulation, one might assume that the interest rate will affect the allocation of the firm's internal resources, provoking them to accumulate financial capital when the interest rate is increasing. This is a strategy to sustain the generation of internal profits, when investment in physical assets is not increasing. In aggregate terms this

(6) This perverted combination of high real interest rates and low real exchange rate has been observed in the Brazilian economy since economic opening and it has been appointed as one of the main obstacles to increasing policy space for the success of long-term economic policies. See, for instance, Bresser-Pereira and Nakano (2002); Bresser-Pereira and Gala (2008); Bresser-Pereira et al. (2014). 
might mean that, in a scenario of increasing interest rates, capital accumulation might not increase, not only because the debt service is increasing, but also because firms allocate resources to the financial market ${ }^{7}$.

A higher interest rate also attracts more foreign capital than is necessary to balance the current account, leading to an appreciation trend of the local currency ${ }^{8}$. This trend will work as a disincentive to invest in the production of more technologically sophisticated goods and an incentive to greater specialization in the production of goods and services in which the economy has comparative advantages. Moreover, in periods of accelerated growth, the overvalued exchange rate will contribute to a faster growth of imports in relation to investment in capital formation, indicating that part of domestic demand is transferred abroad 9 .

Finally, an appreciation trend of the real exchange rate has negative effects on overall competitiveness, as labour unit costs will tend to increase above productivity. The impact of higher labour unit costs on firms' cost structure will induce them to substitute domestic production for imports, moving the economy in the opposite direction in relation to the structural change desired to increase potential output. In this case, an early deindustrialization process would be observed, with negative consequences on short-term growth of output and productivity ${ }^{10}$. Export competitiveness is also jeopardized, implying that the long-term balance of payment constraint to grow will increase. Even the potential stimulus to aggregate demand growth coming from an increase in the labour share in total income may be reduced due to the appreciation trend of domestic currency, as part of this stimulus will be transferred abroad.

Put in another way, the effects on income distribution of the 'exogenous' increase in the real wages are amplified by the loss of autonomy in monetary policy that imposes high interest rates to attract foreign flows, maintaining the appreciation trend in the real exchange rate. In this context, profits of productive firms are reduced with an impact on aggregate savings, assuming that the workers' propensity to save is lower than the entrepreneurs. As a result, the economy tends to be more dependent on external savings, and as Kregel (2004) argues, more prone to external shocks. Moreover, the reduction in aggregate savings in the form of retained earnings by domestic firms would result in a fall in investment in subsequent periods.

(7) For a discussion on the behaviour of the investment rate in Brazil in the 1990s and 2000s, see Feijo et al. (2015) and Feijo et al. (2016).

(8) For an estimate of the 'optimal' long-term real exchange rate in Brazil, see Nassif et al. (2015a); Oreiro and Araújo (2013); Marconi (2012).

(9) According to the structuralist literature, the higher the share of more technologically-intensive sectors in the productive structure of the economy, the higher the productivity growth of the whole economy. According to Ferrari, Freitas and Barbosa Filho (2013, p. 76), productivity increases in the tradable sectors make it possible to raise the salaries of all sectors of the economy, while in the non-tradables sector, the only way to absorb the increase in wages is by increasing prices.

(10) According to the Kaldor-Verdoorn Law. 
In short, financial integration in an asymmetric international financial market ${ }^{11}$ can lead to an overvalued real exchange rate, which, through its distributional effects, increases dependence on foreign savings and consequently leaves little space for a decrease in the domestic interest rate. The interest rate differential inhibits investment in capital accumulation, especially industries with higher technological content, and exports, as long argued by Bresser-Pereira (2010). In the case of a reversal of the capital flow, the economic conditions become more adverse, driving an increase in the interest rates to attract capital, increasing the burden on public and private loans, leading the economy to a semi-stagnant growth pattern and to an increase in financial fragility in the short-term.

\section{De-industrialization and increasing financial fragility: The Brazilian economy in the $2000 s^{12}$}

The opening of the Brazilian economy did not lead to a structural change towards a more technologically sophisticated industry, as expected. On the contrary, deindustrialization deepened and external fragility increased. The aim of this section is to present the evolution of the Brazilian economy in the 2000s to show how the policy space has been reduced, the degree of financial integration has increased and perspectives to redeem higher and less volatile growth rates seem to be slim in current times ${ }^{13}$.

A closer look at Brazil's performance in the last two decades shows that during the period immediately after the end of the high inflation regime and economic opening, growth rates were disappointing (1.6 per cent in average, during the 1996-1999 period, see Table 1), while the stabilization period was characterized by external shocks: in 1997 the Asian crisis and in 1998 the Russian crisis. In January 1999, after resisting several speculative attacks against the domestic currency (real), the Brazilian authorities changed the exchange rate regime and allowed the real to be devalued. This change was followed by the introduction of inflation targeting. In the 2000s, growth picked up to an average annual rate of 3.8 per cent until 2008. The performance in the 2000s can be explained largely by the commodities boom, which implies that the economy was stimulated by the increase in the prices of exported commodities. The period of higher dynamism was short lived, though, because of the international financial crisis in 2008. Since 2011, Brazilian economic growth rate has followed a stop-and-go pattern, and in 2015 it registered the worst result since 1990 $(-3.5 \%)^{14}$. Therefore, financial integration has not delivered a higher dynamic growth rate; as a matter of fact, the average annual growth rate of GDP per capita was 1.4 per cent from 1990 to 2014, much lower than the average annual growth observed before economic opening (1961-1989 period) of 3.1 per cent a year.

(11) For a discussion on Keynes's vision of the hierarchy of the currencies, see Paula et al. (2017).

(12) This section uses part of the material written by two of the authors in another study. See Feijo et al. (2017).

(13) For a long-term analysis of the Brazilian experience of growth and a review of the debate between opposing interpretations, see Bresser-Pereira (2006). For a comparison of the performance among the BRICS, see Nassif et al. (2016) and Ferrari Filho et al. (2006), and Nassif and Feijo (2013) for an analysis of Brazilian performance since the 1980s.

(14) For a discussion on the economic policy after the international financial crisis, see Paula et al. (2015). 
Table 1

Average growth rates of GDP and aggregate Demand - Brazil - 1996-2016*

\begin{tabular}{c|c|c|c|c|c|c}
\hline & GDP & $\begin{array}{c}\text { Private } \\
\text { Consumption }\end{array}$ & $\begin{array}{c}\text { Government } \\
\text { Consumption }\end{array}$ & $\begin{array}{c}\text { Gross } \\
\text { Capital } \\
\text { Formation }\end{array}$ & Exports & Imports \\
\hline $1996-1999$ & 1.6 & 1.5 & 1.1 & 0.0 & 5.2 & 0.7 \\
\hline $2000-2008$ & 3.8 & 3.5 & 2.6 & 4.5 & 8.3 & 7.6 \\
\hline $2009-2016$ & 1.2 & 2.1 & 1.5 & -0.6 & 1.8 & 1.1 \\
\hline $1996-2016$ & 2.4 & 2.6 & 1.9 & 1.7 & 5.2 & 3.8 \\
\hline
\end{tabular}

Source: Brazilian Statistical Office, Quarterly National Accounts*. 1996 is the first year for the Quarterly National Accounts on a comparable basis.

The lower growth rates since economic opening were followed by current account deficits in most of the period. Figure 1 shows that current account surpluses were only registered between 2003-2007, during a period of rapid growth in world trade. Figure 1 also shows the evolution of the real exchange rate; it is clear that the current account balance responded to the real exchange rate movements.

Figure 1

Current account balance as a share of GDP and real effective exchange rate index - 1996-2016

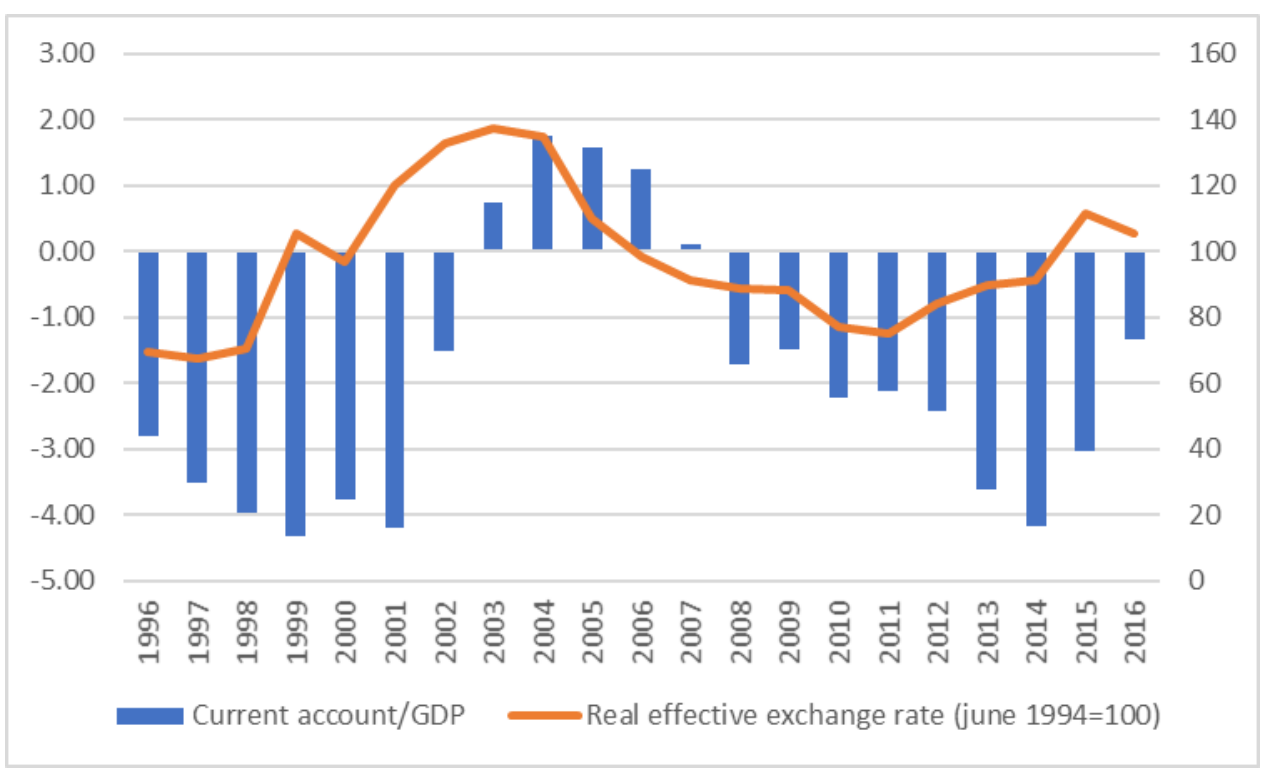

Source: IPEA data and Brazilian Central Bank (Series number 11752).

Likewise, it confirms that there has been a persistent trend in real appreciation of domestic currency in the last decades which was only broken by sudden internal or external shocks, such as in 1999 (due to the speculative attack against the Brazilian real); 2001 (due to a serious electric energy crisis); 2002 (due to negative expectations surrounding the election of 
Luiz Ignacio Lula da Silva, at that time evaluated as a radical leftist by markets); in the aftermath of the September 2008 global financial crisis and in mid-2014 due to the announcement by the Federal Reserve Bank of an increase in the American interest rate, which only took place in December 2015, but precipitated a capital flight). The recent reversion in the exchange rate movement is largely explained by the deepening recession in the country, and a deterioration in the evaluation of future prospects of the economy by rating agencies.

The trend of currency appreciation is a negative effect of the opening of the financial account without appropriate instruments for capital management - i.e., with little room for maneuver to avoid both capital flight and capital flood ${ }^{15}$. Thus, capital opening resulted in increasing dependence on foreign saving and in the exposition of the economy to the volatility of foreign capital. This context explains a 'fear of depreciating', which induces the manipulation of domestic interest rate to attract capital, and as a collateral effect, the currency tends to be overvalued over time.

The long appreciation trend of the Brazilian currency also has a negative impact on the productive structure. One of the most important effects is to increase unit labour costs, with two negative consequences on the long-term growth of the economy. On one hand, firms are encouraged to transfer demand abroad leading to an early de-industrialization process ${ }^{16}$, mainly in sectors which are more technologically advanced and with less comparative advantages. In other words, firms in general and those in less competitive sectors in particular are encouraged to import technology to face increasing labour costs and to catch up with their competitors. On the other hand, increasing labour costs above productivity in a context of an appreciation trend of the real exchange rate implies loss of competitiveness of the exports.

Figure 2 illustrates how the loss in the weight of the manufacturing industry (the most dynamic sector in the economy) in total value added is correlated with the movement of wage appreciation adjusted by productivity.

As a complement to Figure 2, the statistics shown in Table 2 present the evolution of the composition of the trade balance of goods in the 2000s. The manufacturing products were classified according to the intensity in the use of resources, and Table 2 shows the expressive increase in the trade deficit of more sophisticated items such as the scale-intensive goods and the science, engineering and knowledge-based goods. The trade balance of the primary sector, on the other hand, represented more than 60 per cent of total exports of goods on average in the 2000-2014 period. It is clear that the Brazilian export basket is becoming

(15) Bresser-Pereira et al. (2015) also consider the non-neutralization of the dutch disease as contributing to the appreciation trend of the real exchange rate.

(16) See Bresser-Pereira (2010), Oreiro and Feijo (2010), Feijo and Lamonica (2012), Nassif et al. (2015) for a discussion about early de-industrialziation in Brazil, among others. 
increasingly specialized in low value-added products, confirming the de-industrialization process in recent years.

Figure 2

Percentage share of the manufacturing value added in total value added at constant prices and exchange/wage ratio tied to the productivity Index (June/1994=100)

1996-2015

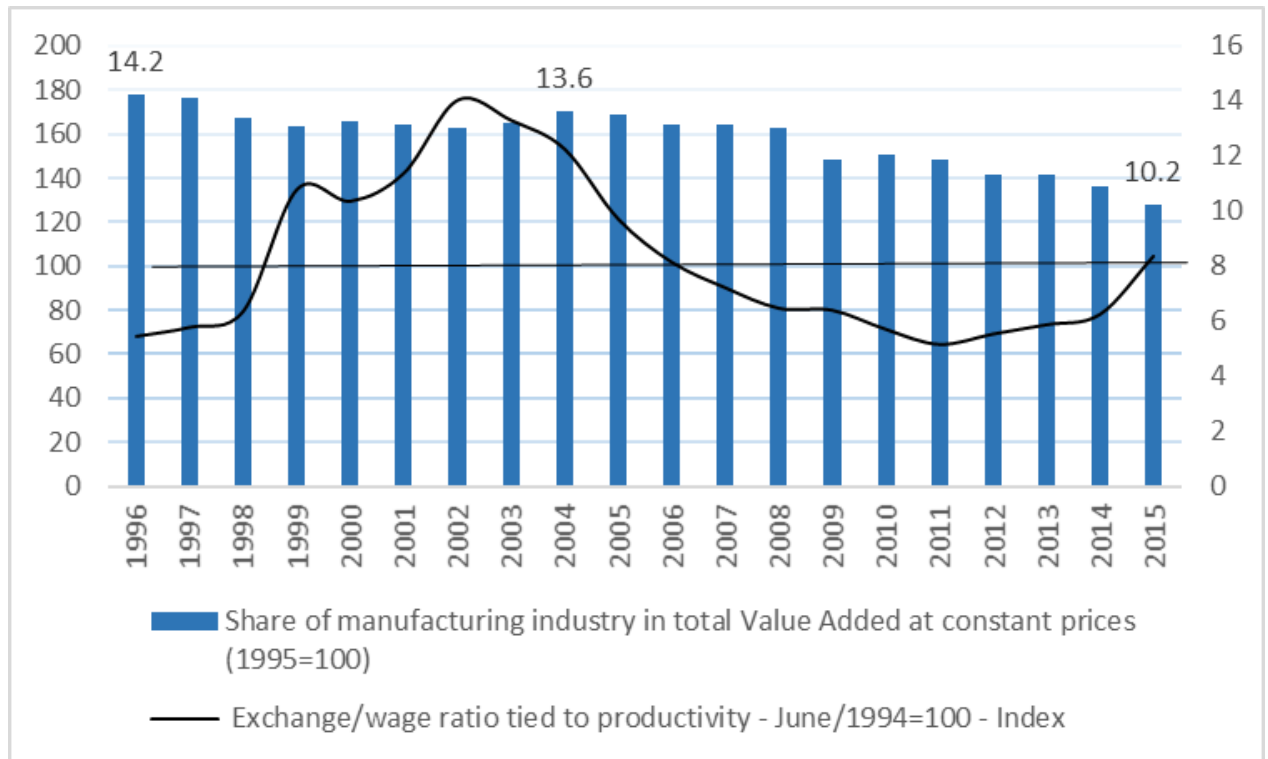

Source: Brazilian Central Bank (series number 11 776) and Brazilian Statistical Office, Quarterly National Accounts.

Table 2

Brazilian annual average trade balance by group of products: 2000-2014 (in US\$ million)

\begin{tabular}{l|c|c|c|c}
\hline Manufacturing Products & $\mathbf{2 0 0 0 - 2 0 0 4}$ & $\mathbf{2 0 0 5 - 2 0 1 0}$ & $\mathbf{2 0 1 1 - 2 0 1 4}$ & $\mathbf{2 0 0 0 - 2 0 1 4}$ \\
\hline Natural Resource Based & 15116.0 & 44026.0 & 74165.1 & 42426.4 \\
\hline Labor-Intensive & 3434.3 & 2747.9 & -2762.6 & 1507.2 \\
\hline Scale-Intensive & 630.0 & -6256.0 & -45293.7 & -14370.7 \\
\hline Science, Engineering and Knowledge Based & -8008.2 & -20541.6 & -43439.6 & -22469.9 \\
\hline Subtotal & $\mathbf{1 1} \mathbf{1 7 2 . 0}$ & $\mathbf{1 9 9 7 6 . 3}$ & $\mathbf{- 1 7 3 3 0 . 8}$ & $\mathbf{7 0 9 3 . 0}$ \\
\hline $\begin{array}{l}\text { Agricultural Products, Fishery and Forestry } \\
\text { Products }\end{array}$ & $\mathbf{4 2 8 3 . 2}$ & $\mathbf{1 2 ~ 1 7 2 . 2}$ & $\mathbf{2 8 ~ 5 3 3 . 8}$ & $\mathbf{1 3 ~ 9 0 5 . 6}$ \\
\hline Non-Classified & -681.5 & 1485.9 & 681.6 & 549.0 \\
\hline Total & $\mathbf{1 4 7 7 3 . 7}$ & $\mathbf{3 3 6 3 4 . 4}$ & $\mathbf{1 1 ~ 8 8 4 . 7}$ & $\mathbf{2 1 ~ 5 4 7 . 6}$ \\
\hline Sour
\end{tabular}

Source: IPEA data, original source FUNCEX Bulletin. 
The recurrent current account deficits observed during almost the entire period since price stabilization (Figure 1), increased dependence on capital inflows. To sustain capital flow, the Brazilian central bank had little choice but to maintain a positive interest rate differential to ensure balance of payments solvency and temporarily relieving the foreign exchange constraint, mainly after the international financial crisis in 2008.

A monetary policy aimed to attract foreign capital also limits the space for fiscal policy, given that to sustain real interest rates at a relatively high level leaves little room for maneuver for the government to manage counter-cyclical fiscal policy. This is clear in the Brazilian case, as until 2008, the primary result had been maintained at above three per cent of GDP, notwithstanding the fluctuation in the output growth rate over time (Figure 3). After 2008, the primary result diminished as a percentage of GDP, but was still positive even after the first signs of increased capital volatility, increased current account deficits, and the persistence of the appreciation trend of the real exchange rate that would reduce the rate of output growth. After 2014, due to the increased deceleration of GDP, the primary result was negative for the first time since 2002, and interest payments on public debt as a share of GDP jumped from 4.7 per cent in 2013 to 5.5 per cent in 2014 and to 8.5 per cent in 2015 . As a result, the public debt ratio deteriorated. The deterioration of the public debt ratio increases risk aversion, which in turn demands higher primary surplus, reinforcing a pro-cyclical fiscal policy.

Figure 3

Primary result and interest payment as a share of GDP and GDP annual growth rate - 2001-2015

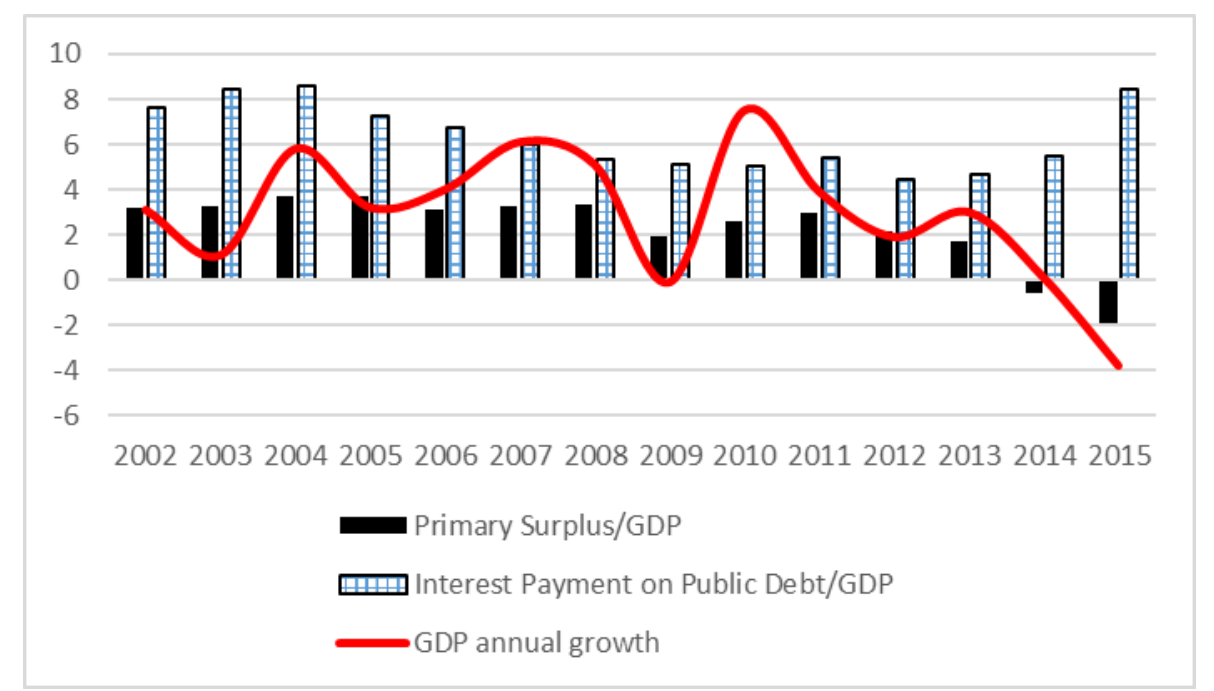

Source: Brazilian Central Bank and Brazilian Statistical Office, Quarterly National Accounts.

If policy space has been narrowed by financial integration, Brazil's efforts to attract capital have been successful, given that the accounts of the international investment position (Figure 4) signal a large amount of capital inflow into the country, in particular after 2005. 
Figure 4

Long and short-term investment position and current account balance (2001-2015) US\$ Million

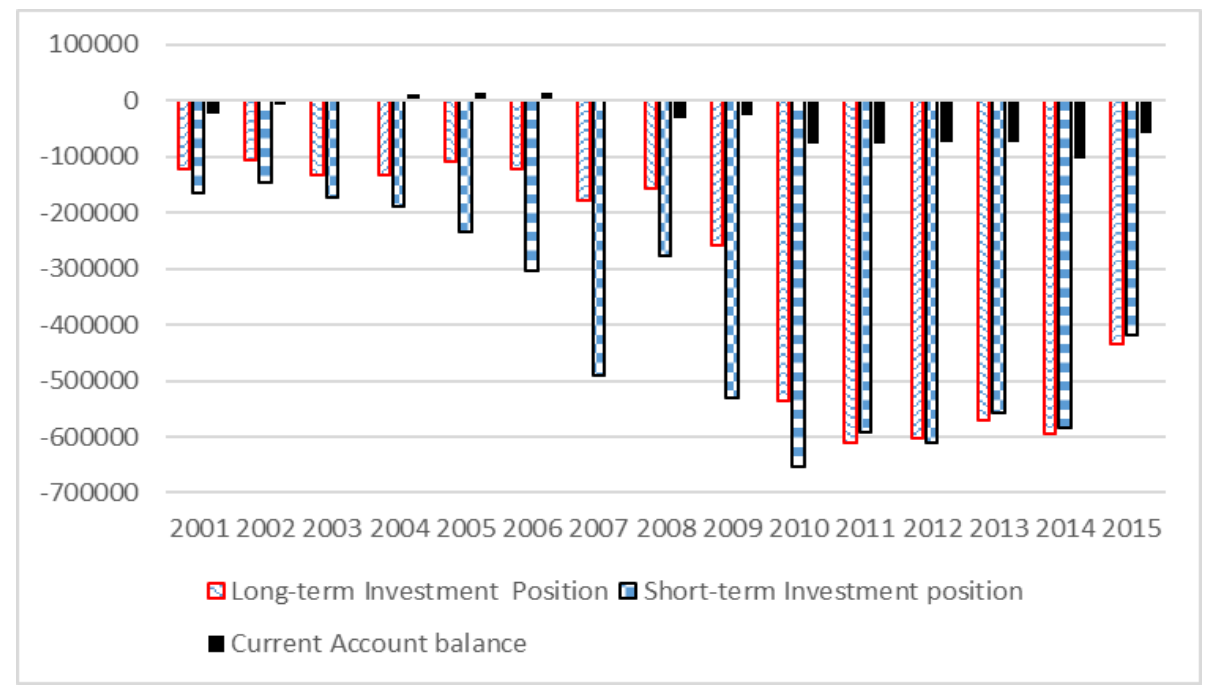

Source: Brazilian Central Bank. Authors' own elaboration.

However, comparing the evolution of the trade (goods and services) and primary income balances since 1995, it is clear that the possibility of building 'real' capital, in Kregel's terminology, to reduce the propensity to external fragility was only observed during the short period of the trade boom from 2004 to 2007. After 2008, trade and primary income deficits reached higher levels, showing that the Brazilian external position is deteriorating, in spite of the positive capital inflow.

Figure 5

Trade and primary income balances: 1995-2015 (US\$ Millions)

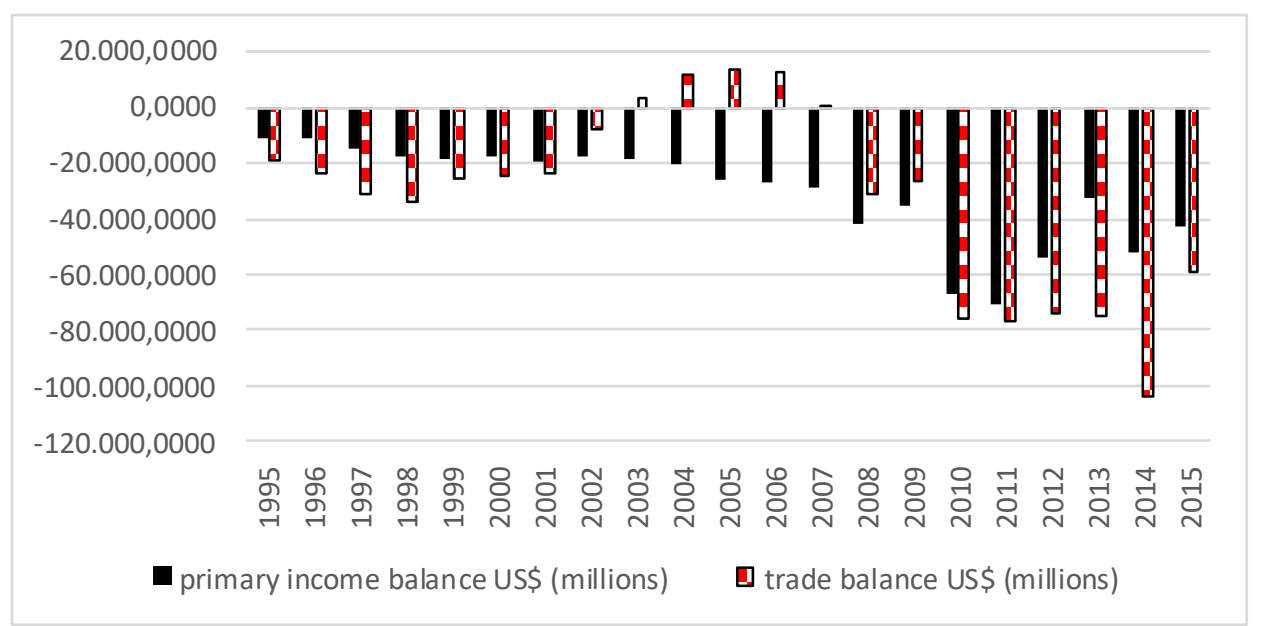

Source: Brazilian Central Bank. 
The strategy to accumulate reserves in the Brazilian case (Figure 6) increased significantly after 2005 , due to the trade surplus generated during the commodity boom and to the expressive increase in capital inflows. Even so, from 2012 onwards the amount of accumulated reserves responded to less than 40 per cent of the net short-term investment (Figure 4), indicating that the degree of external fragility of the country is increasing. Figure 6 also shows the evolution of the GDP growth rate to illustrate another negative aspect of financial integration, which is expressed by the necessity to sustain a high volume of liquid assets as foreign reserves, in a recessionary context. In this sense we can say that the policy of accumulation of foreign reserves also reduces the policy space of developing economies that are financially integrated.

Figure 6

Foreign Reserves (US\$ million) and GDP growth rate (percentage)

2001-2016

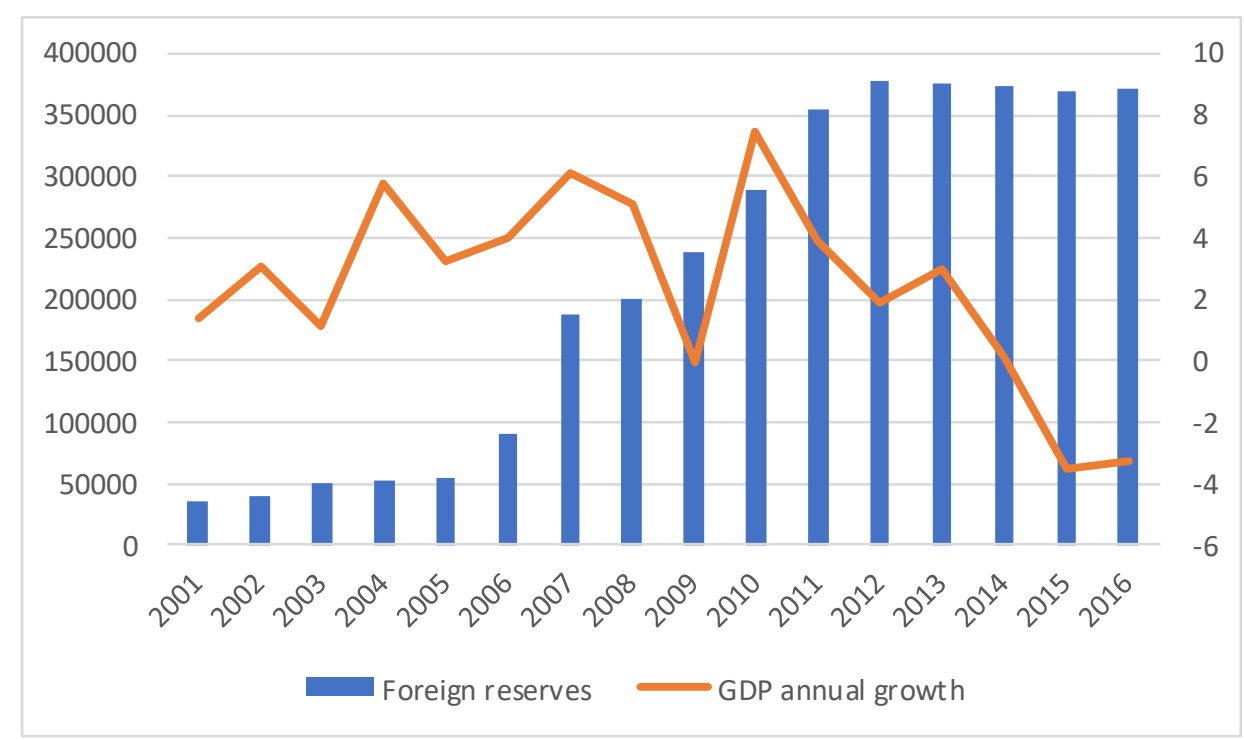

Source: The Brazilian Central Bank and The Brazilian Statistical Office, Quarterly National Accounts.

In sum, given Brazilian economic performance in the last two decades, recovery of the former dynamism, as seen in the post-War period, is unlikely. This is because policy space has been greatly narrowed due to capital opening, which is leading the economy to a Ponzi financial posture ${ }^{17}$.

(17) It is worth quoting Akyuz (2013, p. 3), who warns about the prospects for developing countries in the new economic environment once the world economy restores its growth path: "Even if the crisis in the North is fully resolved, DCs [developing countries] are likely to encounter a much less favourable global economic environment in the coming years than they did before the onset of the Great Recession, including weaker and/or unstable growth in major AEs [Asian economies] and China, higher US interest rates, stronger dollar and weaker commodity prices. Indeed, they may even face less favourable conditions than those prevailing since the onset of the crisis, notably with respect to interest rates, capital flows and commodity prices. Consequently, in order to repeat the spectacular growth, they had enjoyed in the run-up to the crisis and catch up with the industrial world, DCs need to improve their own growth fundamentals, rebalance domestic and external sources of growth and reduce dependence on foreign markets and capital." 
Financial liberalization and structural change: the Brazilian case in the 2000s

\section{The effects of international liquidity on the productive structure: an econometric exercise for the Brazilian economy for the 1999-2015 period}

The aim of this section is to investigate the relation between structural change and international liquidity through a simple econometric model for the 1999-2015 period. According to our theoretical discussion and the empirical evidence on Brazil in the previous sections, our interest now is to discuss how the effects of financial integration and the increased dependence on foreign savings have influenced the share of the industrial sector in the productive structure. In this sense, the objective is to model the share of industry in aggregate output considering the impact of international liquidity.

Inspired by Barbosa Filho (2005), we capture the international liquidity impact through the ratio of international reserves to external debt. In Barbosa Filho (2005), the author estimates the growth rate of the economy as a function of an inertia term and a proxy to international liquidity. The assumption in his model is that the higher the level of international reserves in relation to the degree of indebtedness of the country, the better the financial conditions to roll over debt commitments. This is expected to have a positive impact on the growth of real income.

In the current study, we are interested in evaluating the evolution of the share of industry in total GDP, i.e., how the productive structure evolved in a context of financial integration. In this sense, the expected relation between financial integration and structural change should be negative given that, according to our former discussions, financial integration reduces policy space for developing economies to implement long-term economic policies. Our econometric exercise will also add dummy variables to increment the significance of our results. The dummies are justified to incorporate specific episodes of external financial instability during the period of our analysis ${ }^{18}$. Therefore, we run four models and the specification of each model is presented below.

Model 1: explains the share of the industrial sector in total output with an inertia term and the international liquidity variable:

$$
g_{(I N D / G D P) t}=\beta_{0}+\beta_{1} g_{(I N D / G D P) t-j}+\beta_{2} \Delta l_{t-1}+u_{t}
$$

Where (see Appendix for the description of the variables and the statistical sources):

$g_{(I N D / G D P)}$ is the growth rate of the share of industrial output on GDP.

$\beta_{o}$ is the constant term,

$g_{(I N D / G D P) t-j}$ is the growth rate of the inertia term where $j$ is the number of lags $L(\ldots)$,

$\Delta l_{t-1}$ captures the international liquidity variation over time.

Model 2: Model 1 with a multiplicative dummy controlling the international liquidity boom:

$$
g_{(I N D / G D P) t}=\beta_{0}+\beta_{1} g_{(I N D / G D P) t-j}+\beta_{2} \Delta l_{t-1}+\beta_{3} B \Delta l_{t-1}+u_{t}
$$

Where $\beta_{3} B$ is the parameter of the multiplicative dummy starting in the first quarter of 2006.

(18) Multiplicative dummies impact the angular coefficient and dummy variables impact the constant term. 
Carmem Feijo, Marcos Tostes Lamônica, Serigiano Silva Lima

Model 3: Model 2 with an additive dummy controlling the international financial crisis:

$$
g_{(I N D / G D P) t}=\beta_{0}+\beta_{1} g_{(I N D / G D P) t-j}+\beta_{2} \Delta l_{t-1}+\beta_{3} B \Delta l_{t-1}+\beta_{4} C f_{t}+u_{t}
$$

Where $\beta_{4} C_{f}$ is the parameter of the additive dummy for the 2008 crisis.

Model 4: Model 3 with an additive dummy to capture the impact on the Brazilian economy of the European international liquidity crisis:

$$
g_{(I N D / G D P) t}=\beta_{0}+\beta_{1} g_{(I N D / G D P) t-j}+\beta_{2} \Delta l_{t-1}+\beta_{3} B \Delta l_{t-1}+\beta_{4} C f_{t}+\beta_{5} C_{t}+u_{t}
$$

Where $\beta_{5} C$ is the parameter of the additive dummy for 2012 .

\section{Estimation Method}

We estimated the four models using the OLS method. This method was chosen since it offers the best linear unbiased estimator ${ }^{19}$, in the case that endogeneity is not observed among the variables, as indicated by our theoretical reference.

The two variables - share of industry to GDP and the proxy for international liquidity - presented unit roots and were corrected by the use of first difference. The Dickey-Fuller Augmented test indicated that the series are I (1). The trace and Max-Eigen statistics of the Johansen test did not reject the hypothesis of no cointegration and so the models were estimated in difference for the unit root correction.

The dummies introduced in the models (2, 3 and 4) were identified by the One-Step Forecast recursive test, as displayed in Figure 7. The test showed three possible breaks in the international liquidity series: at the end of 2005 and beginning of 2006; at the end of 2008 and in 2012.

In the first case a sharp increase in the level of international reserves was observed that became superior to the external debt. At the end of 2008 and in the first quarter of 2009 the international financial crisis severely hit domestic output which decreased rapidly. In 2012, following the world recession, the Brazilian economy decelerated in relation to the previous year, initiating a downturn in terms of growth.

All these effects were captured by dummy variables in order to control the structural breaks, and thus give stability to the estimated parameters. Therefore, as the dummies were introduced into the models, the estimated equations started to show better statistical adjustments.

(19) According to the Gauss-Markov theorem. 
Figure 7

Results for the recursive One-Step Forecast test for Model 1

2000-2015

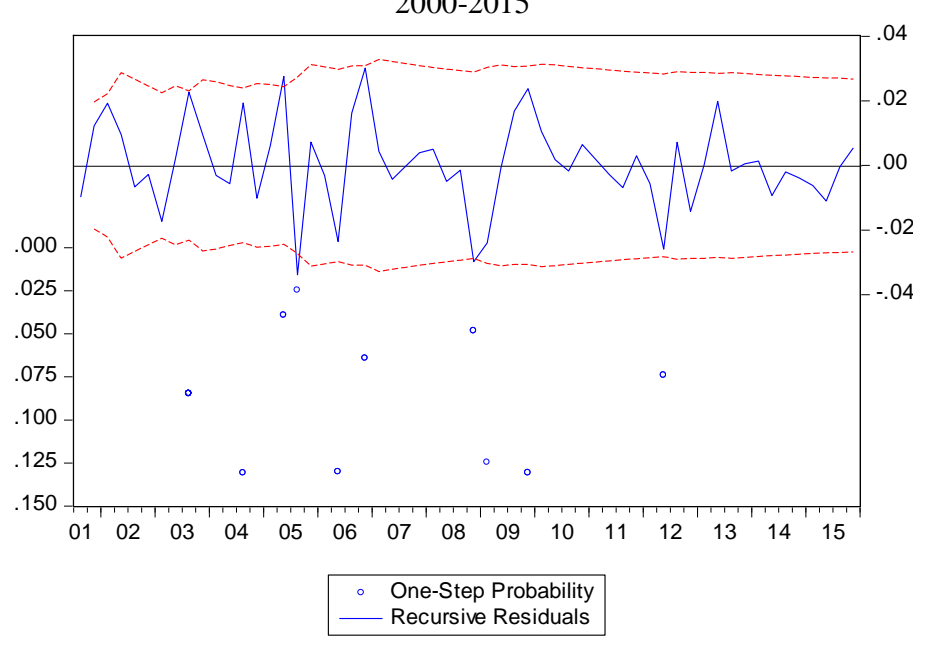

Analysis of the Results (Table 3$)^{20}$

The models show a six quarters lag for the inertia term, and in the four specifications the inertia component presented the highest coefficient (significant at 5 per cent). The six quarters lag is an indication of the density of the industrial sector as the structure in time $t$ reflects changes taking place a year and a half before.

The international liquidity variable was not significant in all four models. In Model 1, however, with no dummy, this variable presented the expected negative signal. Therefore, this variable was not statistically significant, but it can be considered economically significant.

The following specifications (Models 2, 3 and 4) were run with dummy variables added, and in all of them the dummies presented negative signals. As mentioned, we use dummy variables to capture significant episodes in the international financial markets that impacted the international liquidity of the country. Thus, the dummy for the sharp boom in the level of reserves in 2006 (Models 2, 3 and 4), albeit a positive indication for the country in the sense that it presented a better performance in foreign trade, had a negative impact on the industrial sector. Indeed, the commodities boom can be appointed as being responsible for increasing the degree of specialization of the country's industrial structure and contributing to the de-industrialization process, as the negative effect on the real exchange rate appreciation was not neutralized by economic policies.

(20) All equations were estimated with robust standard deviation Newey-West, given the basic conditions of a normal distribution of the residue (Jarque-Bera Prob and Durbin-Watson stat), absence of autocorrelation (Jarque-Bera Prob) and heteroscedasticity (White Test Prob). 
In Models 3 and 4 dummy variables were introduced to capture the impact of the international financial crisis (2008 and 2012). As expected, the 2008 international financial crisis (Model 3) had a negative impact on the balance of payments of the country, increasing its external vulnerability. In this sense it had a negative impact on the share of the industrial sector in total GDP. Finally, Model 4 adds another dummy variable and the negative signal reinforces the interpretation that the industrial sector had been negatively affected by financial integration.

Table 3

The effect of international liquidity on the share of the industrial sector in total GDP Method of estimation: Least Squares

HAC standard errors \& covariance (Bartlett kernel, Newey-West fixed)

\begin{tabular}{ccccc}
\hline \hline \multirow{2}{*}{ Variable } & \multicolumn{4}{c}{ MODELS } \\
\cline { 2 - 5 } & 1 & 2 & 3 & $\mathbf{4}$ \\
\hline \hline$g_{(I N D / G D P) t-\epsilon}$ & $0.2059 * *$ & $0.1840^{* *}$ & $0.1731^{* *}$ & $\mathbf{0 . 1 8 7 0} * *$ \\
$\Delta l_{t-1}$ & $(2.6279)$ & $(2.4682)$ & $(2.4043)$ & $\mathbf{( 2 . 5 7 9 4 )}$ \\
& -0.0191 & 0.0676 & 0.0808 & $\mathbf{0 . 0 6 7 9}$ \\
$B \Delta l_{t-1}$ & $(-0.3723)$ & $(1.1064)$ & $(1.4553)$ & $\mathbf{( 1 . 2 1 3 4 )}$ \\
& & $-0.0863 * * *$ & $-0.0879 * * *$ & $\mathbf{- 0 . 0 8 8 5 * * *}$ \\
$C f_{t}$ & & $(-5.5984)$ & $(-5.0949)$ & $\mathbf{( - 4 . 7 3 5 2 )}$ \\
& & & $-0.0280 * * *$ & $\mathbf{- 0 . 0 2 8 5 * * *}$ \\
$C_{t}$ & & & $(-16.721)$ & $\mathbf{( - 1 6 . 3 6 5 )}$ \\
& & & & $\mathbf{- 0 . 0 1 0 8 * * *}$ \\
Constant & -0.0017 & -0.0016 & -0.0007 & $\mathbf{( - 3 . 6 2 6 5 )}$ \\
& $(-0.9868)$ & $(-0.9128)$ & $(-0.4689)$ & $\mathbf{( 0 . 0 4 7 8 )}$ \\
\hline \hline R-squared & $\mathbf{0 . 0 4 3 7}$ & $\mathbf{0 . 1 0 1 2}$ & $\mathbf{0 . 2 4 2 5}$ & $\mathbf{0 . 2 8 2 2}$ \\
\hline \hline Adjusted R-squared & 0.0108 & 0.0539 & 0.1884 & $\mathbf{0 . 2 1 7 0}$ \\
Durbin-Watson stat & 2.0024 & 1.9850 & 2.1977 & $\mathbf{2 . 2 9 0 2}$ \\
Jarque-Bera Prob & 0.6182 & 0.7324 & 0.8133 & $\mathbf{0 . 8 7 0 4}$ \\
White Test Prob & 0.3264 & 0.5757 & 0.8717 & $\mathbf{0 . 9 4 2 0}$ \\
Breusch-Godfrey Prob & 0.7130 & 0.9821 & 0.7518 & $\mathbf{0 . 5 4 3 6}$ \\
F-statistic & 1.3261 & 2.1392 & 4.4819 & $\mathbf{4 . 3 2 5 0}$ \\
Prob(F-statistic) & 0.2734 & 0.1053 & 0.0033 & $\mathbf{0 . 0 0 2 2}$ \\
\hline \hline
\end{tabular}

Notes: $t$ test in brackets; $* * *$ significant at 1 percent; $* *$ significant at 5 percent; Model 4 showed the best adjustment.

The result of Model 4 better illustrates the incremental adjustment of each dummy introduced to capture the effect of the changes in international liquidity on the share of 
industry in GDP in the period. In terms of the $R$ square coefficient, Model 4 explains 28 per cent of the change in the share of the industry in total GDP in the 1999-2015 period ${ }^{21}$.

Finally, we should observe that it is noteworthy that all the dummies have a negative signal since during this time the country did not face external shocks as had taken place at the end of the 1990s. This result confirms the assumption that the financial integration of the economy reduced its policy space (in other words, short-term economic policy tended to be pro-cyclical) and long-term policies, such as the Plano de Sustentação do Desenvolvimento (Sustaining Plan of Investment) and the Plano Brasil Maior (Greater Brazil Plan), for instance, were not successful. De-industrialization has deepened, and the trade balance has evolved towards the export of primary and less sophisticated goods, leaving the foreign sector more vulnerable to shocks in the price of commodities. In this context, to build 'real' capital, in Kregel's terminology, is more difficult and the country is compelled to adopt economic policies to reduce the international liquidity premium, which implies the adoption of pro-cyclical economic policies.

\section{Concluding remarks}

In this paper we have argued that developing countries that open their economies and follow a growth strategy supported on external savings tend to narrow their policy space and become more vulnerable to external shocks. As pointed out in section two, financially integrated developing economies are prone to a Ponzi financial posture. This is so because capital flows play a decisive role in their growth dynamics and tend to show a pro-cyclical pattern. The increased dependence on foreign savings implies that the short-term political economy is destined to maintain high real interest rates and a non-competitive real exchange rate. As discussed in section three, this macroeconomic context does not stimulate capital accumulation and structural change that would allow the economy to build 'real' capital.

The Brazilian economy provides an example of capital opening to promote a continuous reallocation of resources to enhance potential output not generating the expected benefits. As discussed in section four, the main macroeconomic prices did not favour the allocation of resources to promote structural change towards the production of more technologically sophisticated goods. Domestic interest rates tended to be higher than in developed countries and the real exchange rate tended to be volatile and overvalued, increasing labour costs. Fiscal space was limited as the burden of public debt is pro-cyclical. Moreover, external fragility is augmented and so the economy is more vulnerable to external shocks.

(21) It should be mentioned that we also ran three versions of the model without the variation of the international liquidity variable $\left(\Delta l_{t-1}\right)$ but considering the multiplicative dummy $\left(\beta_{3} B \Delta l_{t-l}\right)$. Our aim was to test if the results of the models would improve, since the F-statistics were not significant in Models 1 and 2 (Table 3). We observed that the F-statistics in Model 2 became significant at 5 per cent, but no significant change was observed in Models 3 and 4 . 
Carmem Feijo, Marcos Tostes Lamônica, Serigiano Silva Lima

Our econometric exercise showed that to capture the international liquidity effect on the productive structure we had to introduce dummy variables to incorporate the changes in international liquidity in 2005-2006; 2008 and 2012. The model presented the negative impact of international liquidity on the share of the industry in GDP, as expected. This is interesting, as during this period the Brazilian economy did not suffer any serious episodes of capital flight (from 1999 to 2015), yet the de-industrialization process has deepened and the financial integration of the economy resulted in greater dependence on capital flows.

\section{References}

AKYUZ, Y. Waving or drowning: developing countries after the financial crisis. Jun. 2013. (South Center Research Paper, n. 48). Available at: http://g24.org/wpcontent/uploads/2014/03/RP48 Waving-or-drowning EN.pdf

ARESTIS, P. Financial liberalization and the relationship between finance and growth. In: ARESTIS, P.; SAWYER, M. A handbook of alternative monetary economics. Edgar Elgar, 2006.

AZEVEDO, A F Z de, FEIJO, C.; CORONEL, D. A. A desindustrialização brasileira. Editora Unisinos, 2013.

BACHA, E.; de BOLLE, M. B. O futuro da indústria no Brasil: desindustrialização em debate. Rio de Janeiro: Civilização Brasileira, 2013.

BARBOSA FILHO, N. H. International liquidity and growth fluctuations in Brazil, chapter $13^{\text {th }}$. In: EPSTEIN, G. Financialization and the world economy. Cheltenham, UK: Edward Elgar, 2005.

BIANCARELLI, A. M. A visão convencional sobre a abertura financeira e suas mutações recentes. Estudos Econômicos, v. 40, n. 4, p. 917-942, 2010.

BRAZILIAN CENTRAL BANK. Available at: www.bcb.gov.br. Access in: 2016, Mar.

BRESSER-PEREIRA, L. C. Novo desenvolvimentismo e ortodoxia convencional. In: DINIZ, Eli (Org.). Globalização, estado e desenvolvimento. São Paulo: FGV Editora, 2006.

BRESSER-PEREIRA, L. C. Globalization and competition. Why some emerging countries succeed while others fall behind. Cambridge: Cambridge University Press, 2010.

BRESSER-PEREIRA, L. C.; NAKANO, Y. Uma estratégia de desenvolvimento com estabilidade. Brazilian Journal of Political Economy (Revista de Economia Política), v. 22, n. 3, p. 146-180, 2002.

BRESSER-PEREIRA, L. C.; GALA, P. Foreign savings, insufficiency of demand and low growth. Journal of Post Keynesian Economics, v. 30, n. 3, p. 315-334, 2008. 
BRESSER-PERERA, L. C.; ARAÚJO, E.; GALA, P. An empirical study of the substitution of foreign for domestic savings in Brazil. EconomiA, Brasília, v. 15, p. 54-67, 2014.

BRESSER-PEREIRA， L. C.; OREIRO, J. L.; MARCONI, N. Developmental Macroeconomics: new developmentalism as a growth strategy. London: Routledge, 2015.

CARNEIRO, R. Globalização financeira e inserção periférica. Economia e Sociedade, Campinas, v. 13, p. 57-92, 1999.

CARVALHO, F. J. C. de. The accumulation of international reserves as a defensive strategy: reasons and limitations of self-insurance. In: STIGLITZ, J.; GRIFFITH-JONES, S.; OCAMPO, J. A. (Ed.). Financial markets reform. New York: Oxford University Press, 2009.

FEIJO, C.; LAMONICA, M. Importancia del sector industrial para el desarrollo de la economia de la economia brasileña. Revista de la Cepal, v. 107, n. 2, p. 107-126, 2012.

FEIJO, C.; LAMONICA, M. Policy space in a financially integrated world: the Brazilian case in the 2000s. Panoeconomicus, advanced online publication, 2017. DOI: http://dx.doi.org/10.2298/PAN160502002F.

FEIJO, C.; LAMONICA, M.; BASTOS, J. Accumulation pattern of the Brazilian economy in the 1990s and 2000s. International Review of Applied Economics, v. 29, n. 1, p. 15-31, 2015 .

FEIJO, C.; LAMONICA, M.; BASTOS, J. Why does the investment rate do not increase? Capital accumulation and stabilization policy in the 1990s and 200s in Brazil. Journal of Post Keynesian Economics, v. 39, n. 4, p. 539-561, 2016.

FERRARI FILHO, F; DE PAULA, L. F. Regime cambial, conversibilidade da conta de capital e performance econômica: a experiência recente de Brasil, Rússia, Índia e China. In: SICSÚ, J.; FERRARI FILHO, F. (Ed.). Câmbio e controle de capitais: avaliando a eficiência de modelos macroeconômicos. Rio de Janeiro: Ed. Campus, 2006.

FERRARI, M. A. R.; FREITAS, F. N. P.; BARBOSA FILHO, N. A taxa de câmbio real e a restrição externa: uma proposta da releitura com elasticidades endógenas. Brazilian Journal of Political Economy (Revista de Economia Política), v. 33, n. 1, p. 60-81, 2013.

IBGE. Brazilian Statistical Office. Available at: www.ibge.gov.br. Access in: 2016, Mar.

IPEAdata. Instituto de Pesquisa Econômica Aplicada. Available at: www.ipeadata.gov.br. Access in: 2016, Mar.

KEGEL. J. Was there an alternative to the Brazilian crisis? Brazilian Journal of Economic Policy (Revista de Economia Política), v. 19, n. 3, p. 23-38, 1999. 
Carmem Feijo, Marcos Tostes Lamônica, Serigiano Silva Lima

KREGEL, J. Can we create a stable international financial environment that ensures net resource transfers to developing countries? Journal of Post Keynesian Economics, v. 26, n. 4, p. 573-590, 2004.

MARCONI, N. The industrial equilibrium exchange rate in Brazil: an estimation. Brazilian Journal of Political Economy (Revista de Economia Política), v. 32, p. 656-669, 2012.

McKINNON, R. I. Money and capital in economic development. Washington, DC: Brookings Institution, 1973.

NASSIF, A.; FEIJO, C. Liberal versus neo-developmental convention to growth: why has Brazil shown a poor performance since the 1980s? Brazilian Journal of Political Economy (Revista de Economia Política), v. 33, n. 4, p. 555-576, 2013.

NASSIF, A.; FEIJO, C.; ARAUJO, E. Structural change and economic development: is Brazil catching up or falling behind? Cambridge Journal of Economics, v. 39, p. 1307-1332, 2015.

NASSIF, A.; FEIJO, C.; ARAUJO, E. (2015a) Overvaluation Trend of the Brazilian Currency in the 2000s: Empirical Estimation. Brazilian Journal of Political Economy (Revista de Economia Política), vol. 35, no.1, pp. 3-27.

NASSIF, A.; FEIJO, C.; ARAUJO, E. Structural change, catching up and falling behind in the BRICS's: a comparative analysis based on trade patterns and Thirlwall's law. PSL Quarterly Review, v. 69, n. 278, p. 373-421, 2016.

OCAMPO, J. A. Balance of payments dominance: its implications for macroeconomic policy. Initiative for Policy Dialogue Working Paper Series, Oct. 2013. Available at: http://policydialogue.org/files/publications/Balance_of_payments_dominance_Ocampo.pdf.

OCAMPO, J. A.; STIGLITZ, J. E. Capital market liberalization and development. Oxford Scholarship Online, 2008, May. Available at: http://www.oxfordscholarship.com/view/ 10.1093/acprof:oso/9780199230587.001.0001/acprof-9780199230587.

OREIRO, J. L.; FEIJO, C. Desindustrialização: conceituação, causas, efeitos e o caso brasileiro. Brazilian Journal of Political Economy (Revista de Economia Política), v. 30, n. 2, p. 219-232, 2010.

OREIJO, J. L.; ARAÚJO, E. Exchange rate misalignment, capital accumulation and income distribution: theory and evidence from the case of Brazil. Panoeconomicus, v. 60, p. 381-396, 2013.

PAINCEIRA, J. P. Developing countries in the era of financialisation: from deficit accumulation to reserve accumulation. Research on Money and Finance, School of Oriental and African Studies, 2009. (Discussion Paper, n. 4). 
PAULA, L. F. R.; MODENESI, A.; PIRES, M. C. C. The tale of the contagion of two crises and policy responses in Brazil: a case of (Keynesian) policy coordination? Journal of Post Keynesian Economics, v. 37, p. 408-435, 2015.

PAULA, L. F. R.; FRITZ, B.; PRATES, D. M. Keynes at the periphery: currency hierarchy and challenges for economic policy in emerging economies. Journal of Post Keynesian Economics, v. 40, n. 2, p. 183-202, 2017.

RODRIK, D. Premature deindustrialization. Journal of Economic Growth, v. 21, p. 1-33, 2016.

SHAW, E. S. Financial deepening in economic development. New York: Oxford University Press, 1973.

SICSÚ, J. Rumos da liberalização financeira brasileira. Brazilian Journal of Political Economy (Revista de Economia Política), v. 26, n. 3, p. 364-380, 2006. 
Carmem Feijo, Marcos Tostes Lamônica, Serigiano Silva Lima

\section{Appendix}

Definition of the variables and statistical source

$g_{(I / P I B) t}=$ share of the industry in GDP, quarterly series, seasonally adjusted.

Source IBGE: Quarterly National Accounts.

$\Delta l_{t-1}=$ international liquidity, lagged one quarter, seasonally adjusted obtained as:

$l_{t}=\frac{r_{t}}{D_{t}}$

$r=$ International reserves- liquidity concept - US\$ (million). Source: Brazilian Central Bank

$D=$ Gross external Debt - US\$ (millions). Source: Brazilian Central Bank.

$B=$ dummy 0 before and 1 after 2006T1.

$C_{f}=$ dummy 0 before and after the financial crisis and 1 for 2008T4 - 2009T1.

$C=$ dummy 0 before and after for the 2012 crisis (2012.1 to 2012.4). 